\title{
New Record of Sillago sinica (Pisces: Sillaginidae) in Korean Waters, and Re-identification of Sillago parvisquamis Previously Reported from Korea as S. sinica
}

\author{
Seung Eun Bae ${ }^{1}$, Hyuck Joon Kwun ${ }^{1}$, Jin-Koo Kim ${ }^{1, *}$, \\ Seon-Man Kweon ${ }^{2}$, Chung Bae Kang ${ }^{3}$ \\ ${ }^{1}$ Department of Marine Biology, Pukyung National University, Busan 608-737, Korea \\ ${ }^{2}$ National Institute of Biological Resources, Incheon 404-170, Korea \\ ${ }^{3}$ Marine Biodiversity Institute of Korea, Sejong 339-012, Korea
}

\begin{abstract}
A single specimen of the genus Sillago, collected from Gwangyang, Korea, in May 2009, is characterized by XI first dorsal fin spines, 3 or 4 rows of melanophore pattern along the second dorsal fin membrane, and a darkish posterior margin of the caudal fin. Our specimen was identified as Sillago sinica reported as a new species; this identification is confirmed by mitochondrial DNA cytochrome oxidase subunit I sequences, which show that our specimen corresponds to $S$. sinica $(d=0.000)$ and differs from the congeneric species Sillago parvisquamis $(d=0.170)$. Comparisons of Korean specimens previously reported as $S$. parvisquamis with specimens of $S$. sinica show that the $S$. parvisquamis specimens are actually $S$. sinica. We propose the new Korean name "buk-bang-jeom-bo-ri-myeol" for $S$. sinica.
\end{abstract}

Keywords: first record, Sillago sinica, Sillago parvisquamis, re-identification, Sillaginidae, Korea

\section{INTRODUCTION}

The family Sillaginidae, order Perciformes, comprise 31 species in three genera worldwide (Nelson, 2006) and 4 species in 1 genus in Korea (Kim et al., 2005; Kwun and Kim, 2010). The Korean species are Sillago sihama (Forsskål, 1775); Sillago japonica Temminck and Schlegel, 1843; Sillago parvisquamis Gill, 1861; and Sillago aeolus Jordan and Evermann, 1902. Sillaginid fishes are morphologically similar, which has led to considerable confusion in specieslevel identifications (Sano and Mochizuki, 1984). A number of recent molecular phylogenetic and phylogeographic studies of cryptic species have been conducted (Kon et al., 2007; Kai et al., 2011), and the family Sillaginidae has been studied by DNA sequencing (Xue et al., 2010). Kwun and Kim (2010) indicated slight morphological differences between Korean and Japanese specimens of S. parvisquamis. We closely compared S. parvisquamis from Korea (reported by Kwun and Kim, 2010) with Sillago sinica specimens reported by Gao et al. (2011) and performed molecular analyses on a single specimen of S. sinica collected in Gwangyang, Korea.

\section{MATERIALS AND METHODS}

A single specimen of Sillago sinica was collected from Gwangyang, Korea on 29 May 2009. After collection, the specimen was fixed in $10 \%$ formalin after extraction of muscle tissue, and transferred to $70 \%$ ethanol. Muscle tissue was stored in 99\% ethanol. The specimen is deposited in the National Institute of Biological Resources (NIBR), Korea. Counts and measurements followed Hubbs and Lagler (2004) with a vernier caliper to the nearest $0.1 \mathrm{~mm}$. The vertebrae were counted from a radiograph (HA-100; Softex, Tokyo, Japan).

Genomic DNA was extracted from muscle tissue using Chelex 100 resin (Bio-Rad, Hercules, CA, USA). Polymerase chain reaction (PCR) was used to amplify the mitochondrial DNA cytochrome oxidase subunit I (COI) using universal (c) This is an Open Access article distributed under the terms of the Creative Commons Attribution Non-Commercial License (http://creativecommons.org/ licenses/by-nc/3.0/) which permits unrestricted non-commercial use, distribution, and reproduction in any medium, provided the original work is properly cited.

pISSN 2234-6953 eISSN 2234-8190
*To whom correspondence should be addressed

Tel: 82-51-629-5927, Fax: 82-51-629-5931

E-mail: taengko@hanmail.net 
primer set (VF2: 5'-TCAACCAACCACAAAGACATTGG CAC-3' and FishR1: 5'-TACACTTCTGGGTGGCCAAA GAATCA-3') (Ivanova et al., 2007), with PCR solution containing $5 \mu \mathrm{L}$ of genomic DNA, $5 \mu \mathrm{L}$ of $10 \times$ buffer, $4 \mu \mathrm{L}$ of $2.5 \mathrm{mM}$ dNTPs, $1 \mu \mathrm{L}$ of each primer, $0.5 \mu \mathrm{L}$ of FR Taq polymerase (Biomedic, Korea), and distilled water to bring the final volume to $50 \mu \mathrm{L}$. PCR was performed under the following conditions: initial denaturation was for $2 \mathrm{~min}$ at $95^{\circ} \mathrm{C}$, followed by 35 cycles of $30 \mathrm{~s}$ at $94^{\circ} \mathrm{C}$ for denaturation, $30 \mathrm{~s}$ at $61^{\circ} \mathrm{C}$ for annealing, and $30 \mathrm{~s}$ at $72^{\circ} \mathrm{C}$ for extension, with a final extension at $72^{\circ} \mathrm{C}$ for $3 \mathrm{~min}$. The nucleotide sequence was deposited in the DDBJ/EMBL/GenBank databases (accession no. KC708229). The sequence was aligned with ClustalW (Thompson et al., 1994) in BioEdit version 7 (Hall, 1999). The sequences of 4 Sillago species (S. aeolus, S. japonica, S. parvisquamis, and S. sihama), from the National Center for Biological Information database, were used for the sequence comparison. Also, Lateolabrax japonicus (PKU 547; KC708230) was used as an outgroup. The genetic distances were calculated with the Kimura-2-parameter model (Kimura, 1980) in MEGA 5 (Tamura et al., 2011). Neighbor- joining $(\mathrm{NJ})$ tree was constructed in MEGA 5 (Tamura et al., 2011) with 1,000 bootstrap replications.

\section{SYSTEMATIC ACCOUNTS}

Order Perciformes

Family Sillaginidae

\section{1*Sillago sinica Gao and Xue in Gao, Ji, Xiao, Xue, Yanagimoto and Setoguma, 2011}

(new Korean name: Buk-bang-jeom-bo-ri-myeol)

(Table 1, Fig. 1)

Sillago sinica Gao and Xue in Gao, Ji, Xiao, Xue, Yanagimoto and Setoguma, 2011: 256, figs. 1, 3F (type locality: coastal waters of East China Sea, China).

Sillago parvisquamis (non Gill): Kwun and Kim, 2010: 109, figs. 2B, 3B (Korea).

Material examined. NIBR-P0000019930 (previously PKU2043), 1 specimen, $157.0 \mathrm{~mm}$ in standard length (SL),

Table 1. Comparison of meristics and morphometrics of Sillago sinica and S. parvisquamis

\begin{tabular}{|c|c|c|c|c|}
\hline \multirow{2}{*}{$\frac{\text { Characters }}{\text { No. of specimens }}$} & \multicolumn{3}{|c|}{ S. sinica } & \multirow{2}{*}{ S. parvisquamis } \\
\hline & 1 & 53 & 6 & \\
\hline Registration number & $\begin{array}{c}\text { NIBR- } \\
\text { P0000019930 }\end{array}$ & $\begin{array}{l}\text { OCU_FEL100348-100399, } \\
\text { OCU_FEL100403-100404 }\end{array}$ & $\begin{array}{c}\text { CNUC 27077, } \\
\text { CNUC 28569-28573 }\end{array}$ & $\begin{array}{l}\text { FAKU 68748, } \\
\text { FAKU } 86827\end{array}$ \\
\hline Standard length (mm) & 157.0 & $92.3-175.0$ & $133-165$ & $194.5-196.5$ \\
\hline \multicolumn{5}{|l|}{ Counts } \\
\hline Dorsal fin rays & XI-I, 22 & $X-X I-I, 21-22$ & $X-X I-I, 21-22$ & XII-I, 22 \\
\hline Anal fin rays & II, 23 & II, $21-23$ & II, $22-23$ & II, 23 \\
\hline Lateral line scales & 79 & - & $78-79$ & $77-79$ \\
\hline Transverse scales & 7 & $7-8$ & 7 & 7 \\
\hline Vertebrae & 38 & $37-39$ & $37-38$ & 39 \\
\hline \multicolumn{5}{|l|}{ Measurements } \\
\hline \multicolumn{5}{|l|}{ In $\%$ of standard length } \\
\hline Head length & 25.2 & $24.7-29.8(27.0)$ & $25.4-27.0(26.2)$ & $25.2-27.1(26.1)$ \\
\hline Body depth & 14.1 & $11.3-18.4(15.4)$ & $11.9-13.9(13.1)$ & $13.9-16.3(15.1)$ \\
\hline Predorsal length & 30.4 & - & $31.3-33.0(31.7)$ & $31.4-32.9(32.1)$ \\
\hline Preanal length & 51.7 & - & $48.5-52.8(50.5)$ & $50.6-53.0(51.8)$ \\
\hline Prepelvic length & 27.8 & - & $26.5-29.4(28.2)$ & $27.0-29.0(28.0)$ \\
\hline \multicolumn{5}{|l|}{ In $\%$ of head length } \\
\hline Snout length & 42.9 & $33.2-45.1(40.4)$ & $41.7-45.1(43.2)$ & $41.2-41.4(41.3)$ \\
\hline Eye diameter & 15.7 & $15.4-22.7(18.7)$ & $14.4-17.8(16.0)$ & $16.5-18.0(17.3)$ \\
\hline Interorbital width & 22.0 & $19.0-28.1(22.8)$ & $24.5-28.6(26.3)$ & $22.6-25.5(24.0)$ \\
\hline Caudal peduncle depth & 28.5 & $19.3-30.0(24.8)$ & $22.5-27.3(25.5)$ & $21.4-23.5(22.4)$ \\
\hline 1st dorsal spine length & 51.5 & - & $40.2-60.8(51.1)$ & $57.1-60.4(58.8)$ \\
\hline 1st dorsal ray length & 39.1 & - & $23.9-43.7(34.3)$ & $41.5-44.9(43.2)$ \\
\hline 2nd anal spine length & 18.2 & - & $18.5-21.7(19.8)$ & $24.2-25.1(24.7)$ \\
\hline 1st anal ray length & 29.8 & - & $25.2-30.8(28.3)$ & $36.5-38.3(37.4)$ \\
\hline Pectoral fin length & 69.9 & - & $63.6-72.3(66.8)$ & $49.6-55.9(52.8)$ \\
\hline Pelvic fin length & 49.2 & - & $44.7-50.6(47.2)$ & $51.5-58.8(55.1)$ \\
\hline Reference & Present study & Gao et al. (2011) & Kwun and Kim (2010) & Kwun and Kim (2010) \\
\hline
\end{tabular}

Korean name: ${ }^{1 *}$ 북방점보리멸 

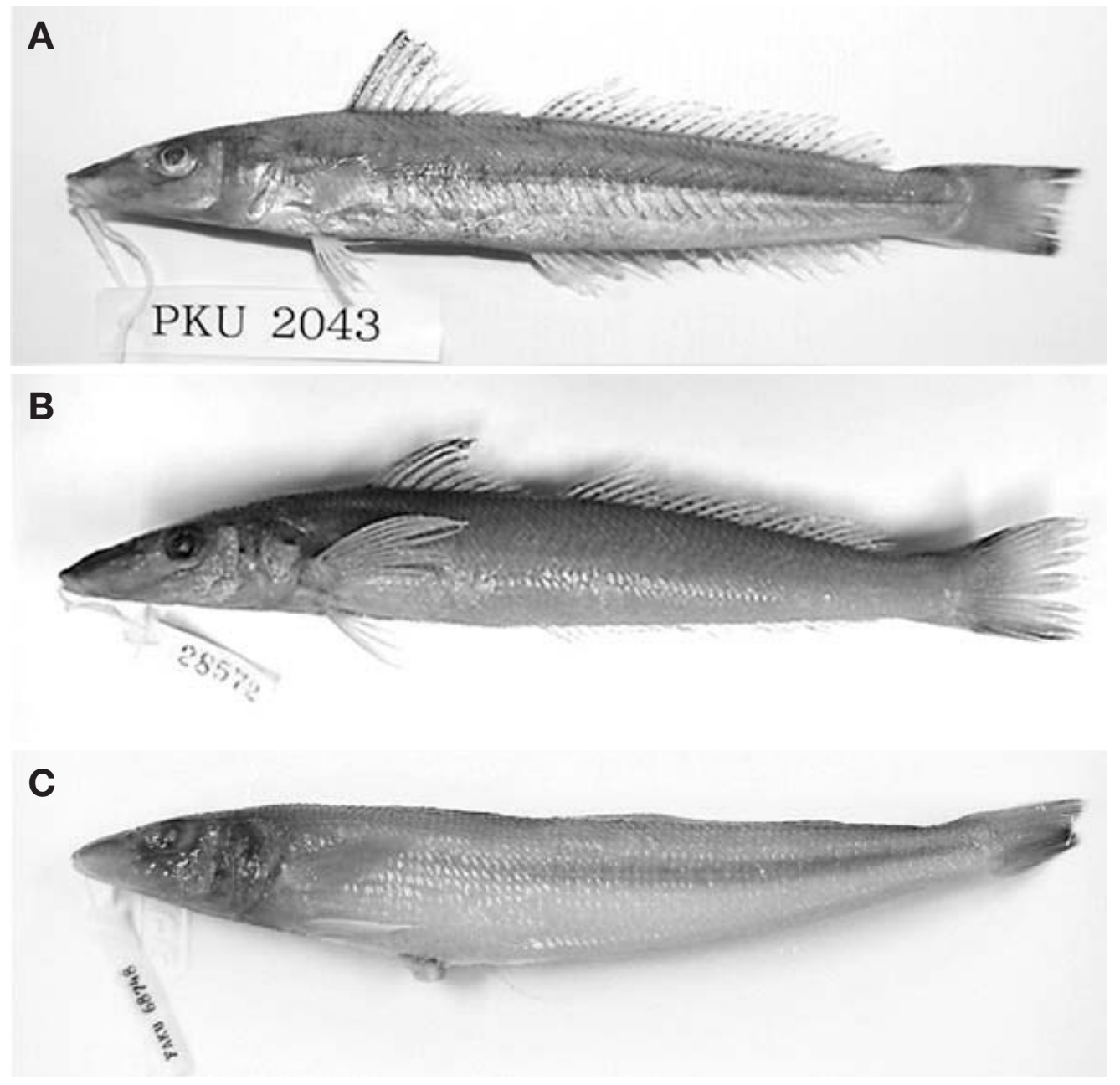

Fig. 1. A, Sillago sinica, NIBR-P0000019930 (previously PKU 2043); B, Sillago sinica, preserved specimen, CNUC 28572; C, Sillago parvisquamis, preserved specimen, FAKU 68748.

Gwangyang, Korea, 29 May 2009; collected by Kwun HJ and Kim JK.

Description. Counts and measurements are shown in Table 1. Body elongated, slightly compressed, and head tapering. Mouth small, terminal, and snout long. Body depth low, and dorsal margin of head slightly sloping. Eyes normal and located middle of the head, and cheek large. Posterior tip of maxilla not reaching to anterior margin of eye, and upper jaw projecting beyond lower jaw. Single row of conical teeth on both jaws. Two pairs of nostrils located in front of eyes. Interorbital region flat and covered with scales. Lateral line extending to caudal fin base with a slight curvature along middle of body. Body and head covered with ctenoid scales; cheek covered with both ctenoid and cycloid scales; only small scales on base of caudal fin. Posterior margin of preopercle serrated. Opercle with a small spine. Two dorsal fins that appear contiguous but completely separated; origin of first dorsal fin located posterior to origin of pelvic fin; origin of second dorsal fin located vertically above origin of anal fin. Second dorsal spine longest, and others gradually became shorter. Pectoral fin slender. Origin of pelvic fin located vertically above lowest base of pectoral fin, and pelvic fin rays shorter than pectoral fin rays. Caudal fin slightly emarginate but nearly truncate.

Coloration. When fresh, body is yellowish-green dorsally and silver-white ventrally. Darkish brown band on snout, gradually fading posteriorly. Two dorsal fins with transparent membranes; first fin darkish anteriorly and second fin with 3 or 4 rows of dusky spots. Pectoral fin pale yellow; pelvic fin white; anal fin membrane transparent with small irregular black spots; caudal fin yellowish with darkish posterior lobe. After fixation, body is bright yellow and silvery white from upper base of the pectoral fin to the ventral side. A single faint stripe is present along middle of body. 


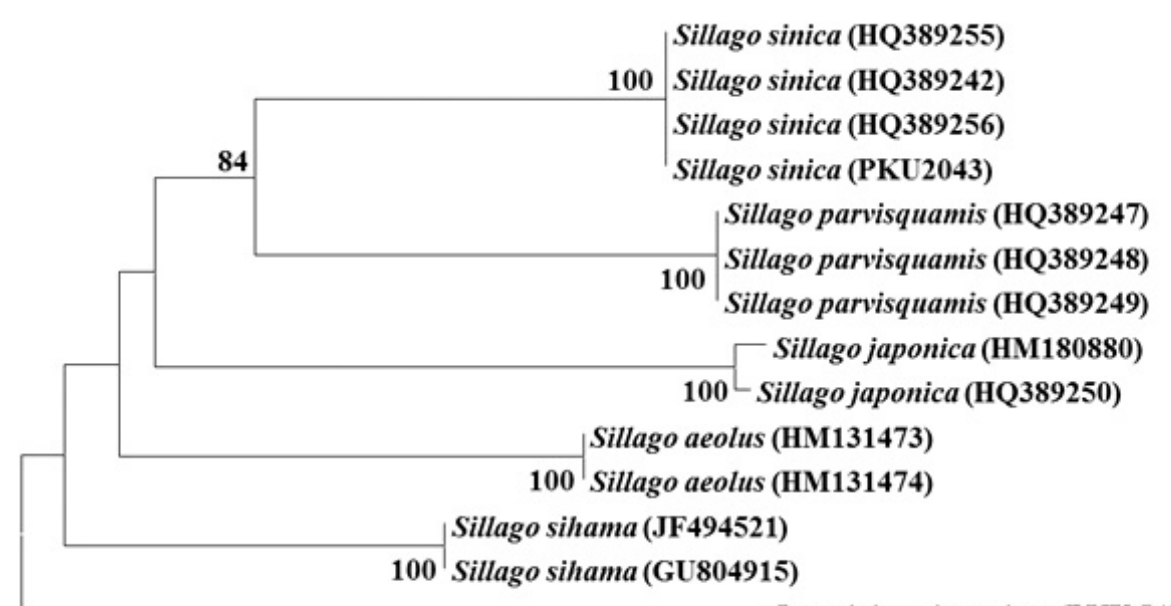

Lateolabrax japonicus (PKU 547)

0.02

Fig. 2. Neighbor-joining (NJ) tree for cytochrome oxidase subunit I gene sequences of 4 Sillaginidae species. The NJ tree was constructed under the kimura 2-parameter (K2P) model using Lateolabrax japonicus as an outgroup. Sillago sinica (PKU 2043) indicate present specimen (NIBR-P0000019930). Bar indicates genetic distance of 0.02 .
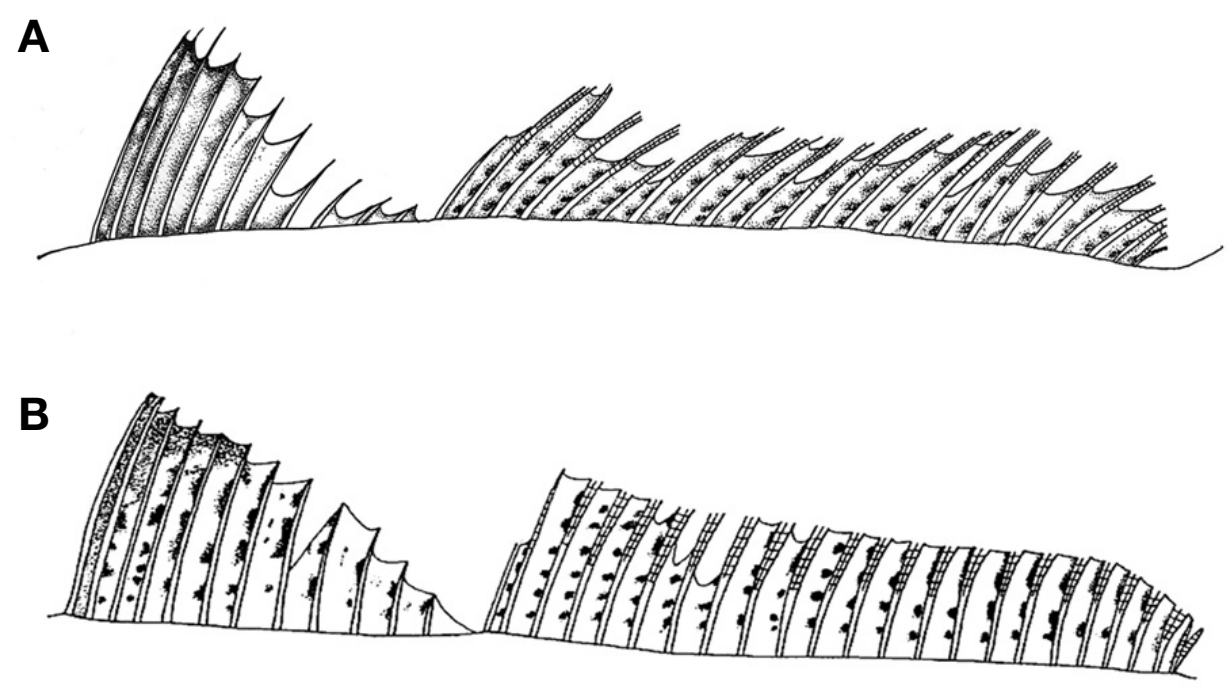

Fig. 3. Dorsal fin showing the melanophore distribution pattern of Sillago species. A, Sillago sinica, NIBR-P0000019930 (previously PKU 2043); B, Sillago parvisquamis (Sano and Mochizuki, 1984: 141, fig. 3B).

MtDNA COI analysis. A total of $550 \mathrm{bp}$ of mitochondrial DNA cytochrome oxidase subnit I (mtDNA COI) were obtained from our specimen and the base pair sequence was then compared with those of four Sillaginidae species. The sequence from our specimen corresponds exactly to that of $S$. sinica $(d=0.000)$ but differs from that of $S$. parvisquamis $(d=0.170)$, which is a morphologically similar species. The sequence from our specimen also shows significant departures from those of $S$. sihama $(d=0.190)$, S. aeolus $(d=0.193)$, and $S$. japonica $(d=0.216)$. A NJ tree shows that the present specimen corresponds to S. sinica (bootstrap value, 100\%) (Fig. 2).

Distribution. Sillago sinica is distributed in China (East China Sea, Yellow Sea, and Bohai Sea) (Gao et al., 2011) and Korea (South Sea) (present study).

Remarks. The specimen in this study was identified as $S$. sinica, a new species recently reported by Gao et al. (2011) as having XI first dorsal fin spines, 38 vertebrae, a second 
dorsal fin with 3 or 4 rows of dusky spots, and a caudal fin with a darkish posterior margin (Table 1, Fig. 3). The specimen is morphologically very similar to $S$. parvisquamis, but is distinguishable from $S$. parvisquamis by the number of first dorsal fin spines (XII-XIII in S. parvisquamis) and the melanophore pattern on the second dorsal fin membrane (56 rows in S. parvisquamis) (Sano and Mochizuki, 1984; Gao et al., 2011). Also, Sillago sinica is distributed in Asia including China and Korea, whereas the congeneric species $S$. parvisquamis is distributed in the South China Sea, Japan, and Taiwan (Shao and Chang, 1978; McKay, 1985, 1992; Hayashi, 2002). In addition, our mtDNA COI analysis showed that our specimen corresponds to $S$. sinica (genetic distance, $d=$ $0.000)$, whereas it differs from $S$. parvisquamis $(d=0.170)$ and $S$. sihama $(d=0.190)$. In the past, the slight morphological variations between the species were considered as regional variations. Recently, however, a number of studies have revealed that these are cryptic species, based on molecular markers (Kon et al., 2007; Ji et al., 2011; Kai et al., 2011; Kwun et al., 2011). Similarly, Kwun and Kim (2010) identified this specimen as $S$. parvisquamis based on some meristic characters and having several rows of dark spots on second dorsal membrane. In addition, they considered morphological differences between Korean and Japanese specimens of $S$. parvisquamis as regional variations, and suggested that molecular investigations of the two groups should be conducted to confirm their species identifications. In present study, we confirmed that $S$. parvisquamis collected in Korea by Kwun and Kim (2010) is S. sinica. If S. parvisquamis is found in Korea in the future, considerable confusion may result it the same Korean name is used to describe both $S$. parvisquamis and $S$. sinica. Therefore, we propose the new Korean name "buk-bang-jeom-bo-ri-myeol" for $S$. sinica, based on its areal distribution in the East China Sea and Yellow Sea.

\section{ACKNOWLEDGMENTS}

We thank Dr. Jong-Young Park (Chonbuk National University, Korea), Dr. Yoshiaki Kai (Kyoto University, Japan) for the loan of the comparative species. This research was supported by the project on survey and excavation of Korean indigenous species of the National Institute of Biological Resources (NIBR) under the Ministry of Environment, Korea.

\section{REFERENCES}

Forsskål PS, 1775. Descriptiones Animalium, Avium, Amphibiorum, Piscium, Insectorum, Vermium, quae in itinere orientali observavit Petrus Forskål. Post mortem auctoris edidit
Carsten Niebuhr. Adjuncta est material medica kahirina atque tabula maris rubric geographica. Ex Officina Molleri, Hauniae, pp. 1-164.

Gao TX, Ji DP, Xiao YS, Xue TQ, Yanagimoto T, Setoguma T, 2011. Description and DNA barcoding of a new Sillago species, Sillago sinica (Perciformes: Sillaginidae), from coastal waters of China. Zoological Studies, 50:254-263.

Gill TN, 1861. Description of a new species of Sillago. Proceedings of the Academy of Natural Sciences of Philadelphia, 13:505-507.

Hall TA, 1999. BioEdit: a user-friendly biological sequence alignment editor and analysis program for Windows 95/98/ NT. Nucleic Acids Symposium Series, 41:95-98.

Hayashi M, 2002. Sillaginidae. In: Fishes of Japan with pictorial keys to the species. English ed.(Ed., Nakabo T). Tokai University Press, Tokyo, pp. 871, 1561.

Hubbs CL, Lagler KF, 2004. Fishes of the Great Lakes region. Revised ed. University of Michigan Press, Ann Arbor, MI, pp. 1-332.

Ivanova NV, Zemlak TS, Hanner RH, Hebert PDN, 2007. Universal primer cocktails for fish DNA barcoding. Molecular Ecology Notes, 7:544-548.

Ji HS, Lee SJ, Kim JK, 2011. Molecular Identification, ontogeny and evolutionary note of Echelus uropterus Leptocephali. Korean Journal of Ichthyology, 23:217-224.

Jordan DS, Evermann BW, 1902. Notes on a collection of fishes from the island of Formosa. Proceedings of the United States National Museum, 25:315-368.

Kai Y, Orr JW, Sakai K, Nakabo T, 2011. Genetic and morphological evidence for cryptic diversity in the Careproctus rastrinus species complex (Liparidae) of the North Pacific. Ichthyological Research, 58:143-154.

Kim IS, Choi Y, Lee CL, Lee YJ, Kim BJ, Kim JH, 2005. Illustrated book of Korean fishes. Kyo-Hak Publishing Co., Seoul, pp. 1-615 (in Korean).

Kimura M, 1980. A simple method for estimating evolutionary rates of base substitutions through comparative studies of nucleotide sequences. Journal of Molecular Evolution, 16:111-120.

Kon T, Yoshino T, Mukai T, Nishida M, 2007. DNA sequences identify numerous cryptic species of the vertebrate: a lesson from the gobioid fish Schindleria. Molecular Phylogenetics and Evolution, 44:53-62.

Kwun HJ, Kang CB, Kim JK, 2011. Redescription of the Hawaiian ladyfish Elops hawaiensis from Korea. Korean Journal of Ichthyology, 23:80-84.

Kwun HJ, Kim JK, 2010. A taxonomic review of four Sillaginid fishes (Perciformes) from the adjacent waters of Korea. Korean Journal of Ichthyology, 22:105-114.

McKay RJ. 1985. A revision of the fishes of the family Sillaginidae. Memoirs of the Queensland Museum, 22:1-73.

McKay RJ. 1992. FAO species catalogue. Vol. 14. Sillaginid fishes of the world (family Sillaginidae). An annotated and illustrated catalogue of the Sillago, Smelt or Indo-Pacific whiting species known to date. Food and Agriculture Organi- 
zation of the United Nations, Rome, pp. 1-87.

Nelson JS, 2006. Fishes of the world. 4th ed. John Wiley and Sons, Inc., Hoboken, NJ, pp. 1-601.

Sano M, Mochizuki K, 1984. A revision of the Japanese sillaginid fishes. Japanese Journal of Ichthyology, 31:136-149.

Shao KT, Chang KH, 1978. A revision of the sandborers (Genus Sillago) of Taiwan. Bulletin of the Institute of Zoology, Academia Sinica, 17:1-11.

Tamura K, Peterson D, Peterson N, Stecher G, Nei M, Kumar S, 2011. MEGA5: molecular evolutionary genetics analysis using maximum likelihood, evolutionary distance, and maximum parsimony methods. Molecular Biology and Evolution, 28:2731-2739.

Temminck CJ, Schlegel H, 1843. Fauna Japonica, sive descriptio animalium quae in itinere per Japoniam suscepto annis 1823-
30 collegit, notis observationibus et adumbrationibus illustravit P. F. de Siebold. Pisces, Fauna Japonica Part, 2-4:2172.

Thompson JD, Higgins DG, Gibson TJ, 1994. CLUSTAL W: improving the sensitivity of progressive multiple sequence alignment through sequence weighting, position-specific gap penalties and weight matrix choice. Nucleic Acids Research, 22:4673-4680.

Xue TQ, Ning DU, GAO TX, 2010. Phylogenetic relationships of 4 Sillaginidae species based on partial sequences of COI and cytochrome $b$ gene. Periodical of Ocean University of China, 40:91-98.

Received April 10, 2013

Revised October 1, 2013

Accepted October 5, 2013 